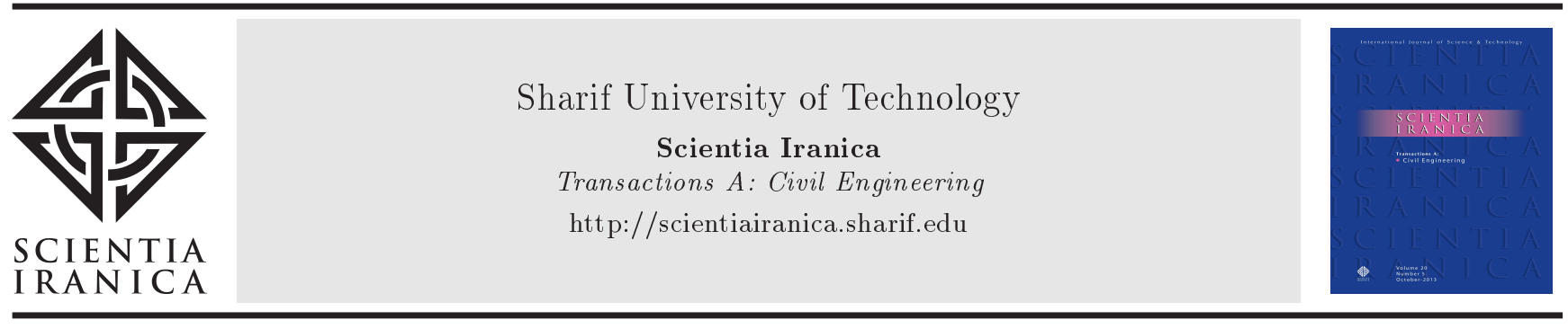

\title{
Parametric study from laboratory tests on twin circular footings on geocell-reinforced sand
}

\author{
P. Fazeli Dehkordi ${ }^{a}$, M. Ghazavi ${ }^{\mathrm{b}, *}$, N. Ganjian ${ }^{\mathrm{a}}$, and U.F.A. Karim ${ }^{\mathrm{c}}$ \\ a. Department of Civil Engineering, Science and Research Branch, Islamic Azad University, Tehran, Iran. \\ b. Department of Civil Engineering, K. N. Toosi University of Technology, Tehran, Iran. \\ c. Faculty of Technology, University of Twente, Enschede, the Netherlands.
}

Received 24 July 2018; received in revised form 16 December 2018; accepted 16 March 2019

\author{
KEYWORDS \\ Bearing capacity \\ factors; \\ Sand; \\ Geocell reinforcement; \\ Circular twin footings; \\ Rigid base.
}

\begin{abstract}
Bearing Capacity (BC) test results are presented for bounded and unbounded twin circular footings on unreinforced and geocell-reinforced (GCR) sand. Analysis of the results demonstrate material, scale and size effects on the $\mathrm{BC}$ for a given combination in materials (sand-GCR), footing (single-twin) and the problem geometric dimensions. The significance of these combinations on $\mathrm{BC}$ and settlements is used to arrive at suitably modified $\mathrm{BC}$ factors for a design that could be generalized. Plots given relative to reference cases for which $\mathrm{BC}$ design solutions are available provide correction factors to modify classical BC equations. Values of the BC and BC factors represent the lumped effect of all or separate problem variables including scale and any experimental limitations. Compared with previous works, these results give deeper critical depths for twin footings on unreinforced and GCR sand and BC higher than 3 times the reference case.
\end{abstract}

(C) 2021 Sharif University of Technology. All rights reserved.

\section{Introduction}

All classical Bearing Capacity (BC) relations were originally derived for a single footing on a soil layer of infinite thickness. Modifications appeared subsequently to arrive at more realistic $\mathrm{BC}$ and settlement measures through a set of factors concerning base confinement [1], interaction with adjacent foundation [2], shape [3], scale [4], and so on. Circular footings received some attention due to their applicability and axi-symmetric nature which approximates $3-\mathrm{D}$ foundations without

\footnotetext{
*. Corresponding author. Tel.: +9821 88779473; Fax: +982188779476

E-mail addresses: Pezhman.fazeli208@gmail.com (P. Fazeli Dehkordi); ghazavi_ma@kntu.ac.ir (M. Ghazavi);

n.ganjian@srbiau.ac.ir (N. Ganjian);

u.f.a.karim@utwente.nl (U.F.A.Karim)
}

doi: $10.24200 /$ sci.2019.51471.2208 the effects resulting from multi-edged footings. Some studies on the behavior of circular footings on sand [5-9] resulted in determination of dimensionless values such as $N_{\gamma}$ (BC) and $S_{\gamma}$ (shape) factors. This foundation type is commonly employed for axisymmetric structures such as silos, cooling towers, tall tanks, etc.

In practice, soils are bounded and experience interference unless foundations are constructed far from each other on a deep layer. The presence of an adjacent foundation [2], reinforcement [10], layering or a rigid base [3] change entirely the shear failure mechanism, footing $\mathrm{BC}$ and settlement behavior. These constraints impose complexities that cannot be easily resolved theoretically, but, for design purposes, can be approximately approached experimentally at different scales and relative dimensions using lumped modified factors for shape $\left(S_{\gamma}^{*}\right)$ and BC $\left(N_{\gamma}^{*}\right)$. By choosing the small scale next to the earlier reported larger scale tests [11], and referring to published results on single footing on 
bounded layer [12-16] or twin footings on unreinforced and geogrid-reinforced stratum [17-22], as reference cases, one can recalculate modified factors and assess their applicability in design.

This study investigates and quantifies: (1) BC from laboratory tests on two sets of circular model footings of different diameters; (2) the separate and coupled influence of different confinement types on the $\mathrm{BC}$ and $\mathrm{BC}$ factors from second neighboring footing, geocell reinforcement, and a rigid base.

\section{Footings BC models for sand}

Mandel and Salençon [1] defined modified BC factor $N_{\gamma}^{*}$ when $H / B \leq 1$ (layer thickness/footing diameter) and found this to be function of $\varphi$ and $H / B$. For unit weight $\gamma$, the $\mathrm{BC}\left(q_{u l t}\right)$ is:

$$
q_{u l t}=0.5 \gamma B N_{\gamma}^{*} .
$$

Meyerhof [3] introduced a modified shape factor $S_{y}^{*}$ due to the rigid base for $H / B \leq 1$ using Mandel and Salençon [1]. For $H / B \geq 1$ Meyerhof [3] proposed $N_{\gamma}=N_{\gamma}^{*}$ and $S_{\gamma}^{*}=0.6$ similar to Terzaghi [23] for an infinite layer. $S_{\gamma}^{*}$ is given by:

$$
S_{\gamma \text { circle }}^{*}=1-m_{2}\left(\frac{B}{L}\right),
$$

where $m_{2}$ is given in a chart for different $H / B$ and $\varphi$, and $L=$ footing length .

Therefore, the BC equation for shallow footing on a bounded sand layer was expanded to:

$$
q_{u l t}=0.5 \gamma B N_{\gamma}^{*} S_{\gamma}^{*}=0.5 \gamma B K_{\gamma}\left(N_{\gamma} S_{\gamma}\right) .
$$

The influence of the friction angle increases in significance on the $\mathrm{BC}$, settlement and on the failure mechanism of square and circular footings when the distance of the rigid base to the floor of the footing decreases [16]. Brown et al. [24] using centrifuge tests presented theoretical methods to determine $N_{\gamma}^{*}$ is conservative. Tournier and Milović [13] in experimental studies on large square footings with different sizes investigated the rigid base effect on $N_{\gamma}^{*}$ and failure geometry. Cerato and Lutenegger [16] performed square and circular plate load tests on sand at various relative densities and footing sizes to consider the scale effect for determining modified BC factor $N_{\gamma}^{*}$ stating that the critical depth of a rigid base is close to $H / B \approx 3$. Eid et al. [14] performed experimental and full-scale numerical studies on square and raft footings on a thin sand layer to simulate the influence of relative density, rigid base and scale effect. These studies consistently reported increasing critical depth within $1.5-3 B$, depending on the footing size and sand relative density.
Stuart [2] introduced an efficiency factor $\zeta_{\gamma}$ for adjacent footings on infinite sand stratum in the following equation:

$$
q_{u l t}=0.5 \gamma B N_{\gamma} \zeta_{\gamma}
$$

where, $\zeta_{\gamma}$ is a ratio of the ultimate bearing pressure for a footing of width $B$, in the presence of the second footing at a distance $d$ (center-to-center), to that of a single isolated footing with the same size $B$.

A twin footing on unbounded sand is more complex requiring different approaches for a $2 \mathrm{D}$ strip [25$28]$ and 3D square footing $[29,30]$ to arrive at an interference factor $\zeta_{\gamma}$. These studies revealed that $\zeta_{\gamma}$ is function of increasing with the decrease in spacing ratio between the footings, reaching a maximum value at certain spacing, depending on $\varphi$ and $B$. In some cases, such as two ring and circular footings, the BC decreases proportionately with increasing distance between footings [21]. The influence zone for interacting square and rectangular footings on layered sand overlaps up to beyond $5 B$ according to Ghosh et al. [31]. Lee and Eun [32], using field plate load tests and finite element analyses, studied the effect of multiple foundations on $\mathrm{BC}$ showing that the pressure-settlement responses of multiple footings are similar to those of the single isolated footing at spacing greater than three times the footing width. Srinivasan and Ghosh [33] found from tests in layered sandy soils on twin circular footings of 75-150 mm diameter, that the interference effect on the $\mathrm{BC}\left(\zeta_{\gamma}\right)$ and settlement $\left(\zeta_{\delta}\right)$ factors, reduces when twin footings are further from each other and upper weaker layer thickness increases.

For twin shallow footings located on a sand layer overlying a rigid base, the equation used in this study is a combined Eqs. (3) and (4), here in terms of defined "modified" efficiency factor $\zeta_{\gamma}^{*}$ :

$$
q_{u l t}=0.5 \gamma B N_{\gamma}^{*} S_{\gamma}^{*} \zeta_{\gamma}^{*}=0.5 \gamma B K_{\gamma}\left(N_{\gamma} S_{\gamma}\right) \zeta_{\gamma}^{*}
$$

where $\zeta_{\gamma}^{*}$ is a ratio of the $\mathrm{BC}$ for a footing located on a sand layer with thickness $H$, in the presence of the second footing at a distance $d$, to that of a single isolated footing with the same $H$ and size.

Planar reinforcement under interfering square and circular footings in sand increases $\mathrm{BC}$ while reducing settlement and tilt, depending on footing size, reinforcement type, and soil properties [17,20,21]. Ghazavi and Alimardani Lavsan [18] determined critical reinforcement width and depth ratios for twin square footings on sand. They concluded that closely spaced footings on one and two geogrid layers produced larger interference factors than when unreinforced. Alimardani Lavasan and Ghazavi [19], using large scale model tests, state that settlement and footing tilt in sand decreases significantly by employing planar reinforcement. 
Eq. (5) can be extended for GCR sand by defining a reinforcement factor $R_{\gamma}$ :

$$
q_{u l t}=0.5 \gamma B R_{\gamma} N_{\gamma}^{*} S_{\gamma}^{*} \zeta_{\gamma}^{*}=0.5 \gamma B R_{\gamma} K_{\gamma}\left(N_{\gamma} S_{\gamma}\right) \zeta_{\gamma}^{*}
$$

\section{Materials and experimental program}

\subsection{Sand}

For all tests, a poorly graded (SP) fine sand with an average friction angle of $36^{\circ}$ is used. Other physical properties of the sand are as follows: specific gravity $G_{s}=2.63$, relative density $D_{r}=68 \%$, dry unit weight $\gamma=15.64 \mathrm{kN} / \mathrm{m}^{3}$, grain size distribution $C_{u}=1.65$, $C_{c}=0.84$, and $D_{50}=0.25 \mathrm{~mm}$.

\section{2. $G C R$}

A commercial drilled geocell type high-density polyethylene (HDPE) produced from novel polymeric made by PRS Mediterranean Inc. is used. The ratio of the geocell pocket size to the diameter of the model footing and the sand cover on the top of the geocell mattress being $D / B=0.82$ and $u / B=0.1$, respectively, gives maximum performance improvement according to Dash et al. [34]. The ratio of the height of geocell $(h)$ to width of footing $(B)$ is $h / B=1$. Geocell reinforcement size $1050 \times 1050 \mathrm{~mm}$ as used is not likely to affect results since only the number of openings which are placed under the footings vary for the model and large scale footings [21].

\subsection{Experimental setup and program}

The GCR sand placement in the box setup can be seen in Figure 1(c). Test box dimensions $1100 \mathrm{~mm}$ length $\times$ $1100 \mathrm{~mm}$ width and $1000 \mathrm{~mm}$ height are used. The dimensions are confirmed by preliminary numerical analysis FLAC 3D [35] showing negligible box walls and base boundary effects. The floor of the box is made from rough concrete. The box is connected to the rigid loading frame with a pneumatic jack (Figure 1(a)) with which the footings are displacement-loaded at a constant rate of $10 \mathrm{~mm} / \mathrm{min}$. Rigid plastic circular footings $150 \mathrm{~mm}$ in diameter are used throughout the table program. For modeling rough footings, the bottoms of the footings are glued to the rough sand paper. Two rigid steel plates are used, in which ball bearings are pointed to a half-sphere shape sitting in the calotte zone at the center of the plates and located on each footing. The setup is such that footings can tilt freely without unfavorable effects from oblique loading. Although former studies show that tilt value due to the interference effect for this range of footing size is negligible [21]. The load is transmitted equally to the footings via the rigid beam.

All tests showing in the test program detailed in Table 1 are performed under dry conditions. A total of 41 tests on single and twin footings and four series of plate load tests are performed. To ensure the accuracy and consistency of the test procedure, seven tests are repeated on the footing on unreinforced and GCR sand,
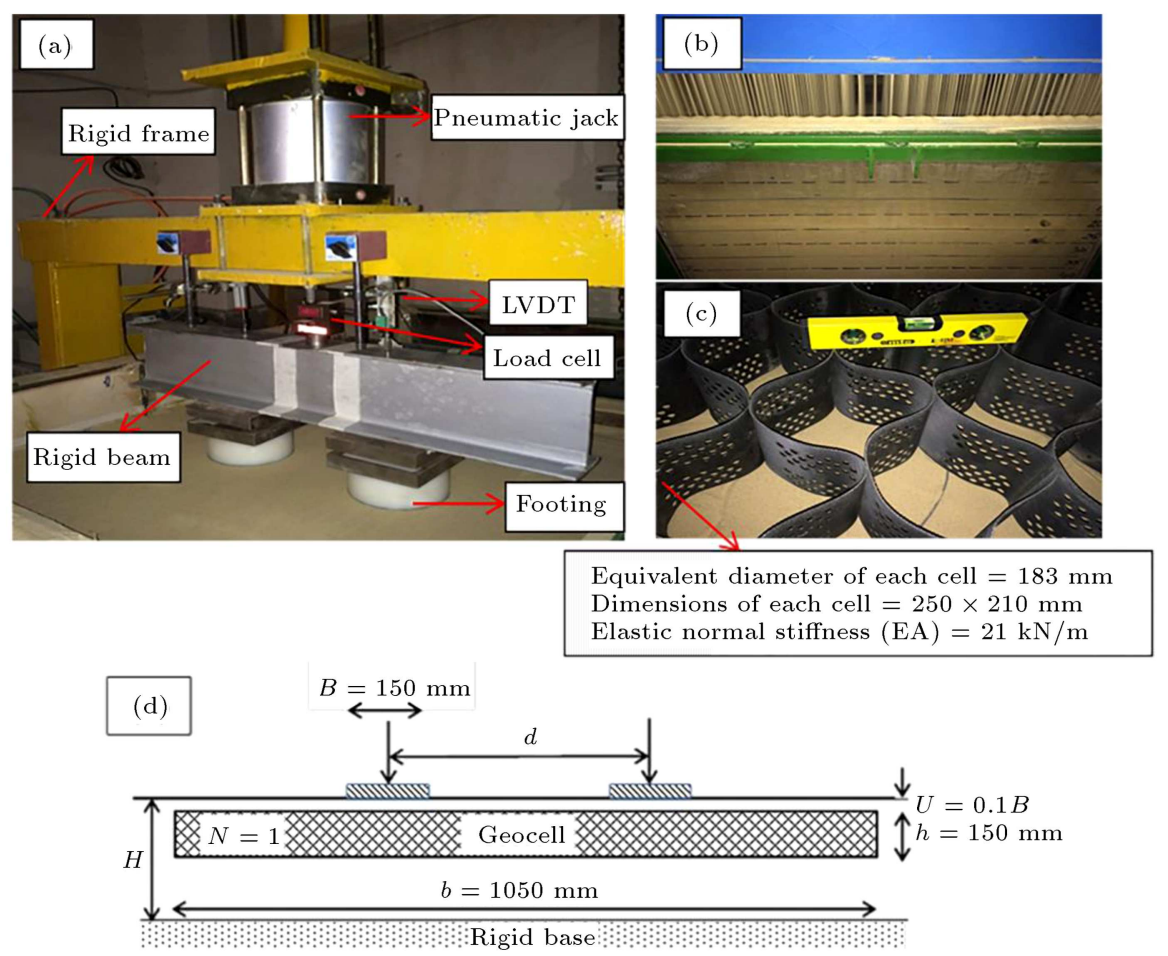

Figure 1. Test setup: (a) Load frame and sand box, (b) sand raining in the box, (c) geocell-reinforced (GCR), and (d) schematic view cross sectional. 
Table 1. Details of model test series.

\begin{tabular}{cccccc}
\hline \multirow{2}{*}{ Test series } & $\begin{array}{c}\text { Type of } \\
\text { footing }\end{array}$ & $\begin{array}{c}\text { Type of } \\
\text { reinforcement }\end{array}$ & \multicolumn{2}{c}{ Variables } & \multirow{2}{*}{ No. of tests } \\
\cline { 3 - 4 } & & & $\boldsymbol{H} / \boldsymbol{B}$ & $\boldsymbol{d} / \boldsymbol{B}$ & \\
\hline A & Single & Unreinforced & $0.5,1,2,3,4,6$ & - & $6+1^{*}$ \\
B & Single & Reinforced & $2,3,4,6$ & - & $4+1^{*}$ \\
C & Twin & Unreinforced & $0.5,1,2,3,4$ & $1,2,3$ & $15+3^{*}$ \\
D & Twin & Reinforced & $2,3,4$ & $1,2,3$ & $9+2^{*}$ \\
\hline
\end{tabular}

*The tests were conducted two times to verify the repeatability of the test data.

resulting in only $4 \%$ deviations, which seem to be small for geotechnical applications. Two Linear Variable Differential Transducers (LVDTs) with the precision of $\pm 1 \%$ of the $100 \mathrm{~mm}$ provided a measure of the average displacement of the footings. A pouring method is used from a constant height of $500 \mathrm{~mm}$ to form the test bed including the geocell in $100 \mathrm{~mm}$ thick layers with a relative density of $68 \pm 5 \%$ (medium compact density) (Figure 1(b)). A S-shaped load cell (accuracy $\pm 0.01 \%$ and full-scale capacity of $50 \mathrm{kN}$ ) and LVDTs are connected to the loading frame over a model jointed to a data logger.

\section{Results and discussion}

To investigate the effect of a rigid base on $\mathrm{BC}$ factors, a ratio correction factor $K_{\gamma}$ is defined as:

$$
K_{\gamma}=\frac{N_{\gamma}^{*} S_{\gamma}^{*}}{N_{\gamma} S_{\gamma}}
$$

where $N_{\gamma}^{*} S_{\gamma}^{*}=\mathrm{BC}$ factors of a single footing on unreinforced sand in the presence of a rigid base, $N_{\gamma} S_{\gamma}=$ BC factors of the same footing in the absence of a rigid base.

To evaluate the influence of the geocell mattress on the footing bearing pressure, a BC Ratio (BCR) can be introduced as:

$$
B C R=\frac{q_{u-\text { Rein. }}}{q_{u-\text { Unrein. }}},
$$

where $q_{u \text {-Unrein }}=\mathrm{BC}$ of the single or two adjacent footings on unreinforced sand and $q_{u-\text { Rein. }}=\mathrm{BC}$ for the same footing on GCR sand at the same settlement.

Considering the influence of all confinement combinations and to measure the simultaneous effects of geocell reinforcement, rigid base and any footing interference on the $\mathrm{BC}$ of each footing relative to the simple case of unbounded, unreinforced single footing, a so-called Ratio Efficiency Factor (REF) is introduced, as follows, obtained by dividing Eq. (6) by Eq. (3).

$$
R E F=\frac{q_{u-\text { Rein.b }}}{q_{u-\text { Unrein.single }}}=K_{\gamma} R_{\gamma} \zeta_{\gamma}^{*},
$$

where $q_{u-\text { Rein.b }}=\mathrm{BC}$ of two adjacent footings resting on reinforced sand with a rigid base and $q_{u-\text { Unrein.single }}=\mathrm{BC}$ of a single isolated footing with the same size on unreinforced sand without a rigid base effect.

\subsection{Behavior of single footing}

\subsubsection{Unreinforced case}

Figure 2 presents all the pressure-settlement results with varying $H / B$ ratio for a footing on unreinforced sand (test series 1). The BC was estimated corresponding to $S / B=10 \%$ [36] and the $N_{\gamma}^{*} S_{\gamma}^{*}$ were back calculated for each test from Eq. (3). A well-defined failure due to the nonlinear behavior of the soil at greater pressures is observed for different $H / B$ values, where for $H / B=0.5$, the ultimate $\mathrm{BC}$ is the largest in comparison to other $H / B$ cases. By increasing $H / B$, the ultimate $\mathrm{BC}$ of the footing decreases until $\mathrm{BC}$ values become approximately constant when $H / B \approx 3$, which is more consistent with previous studies [16]. Generally, BC values for circular footing become constant when $H / B=1.5-3$, depending on soil strength and footing size. This is mainly due to differences in the failure mechanism and the intensity of mean stresses beneath footings of varying sizes. In the larger footing, rupture is less progressive with lower average shear strength mobilized along slip surfaces than in the smaller footing. Increasing footing size tends to decrease the friction angle due to curvature of the

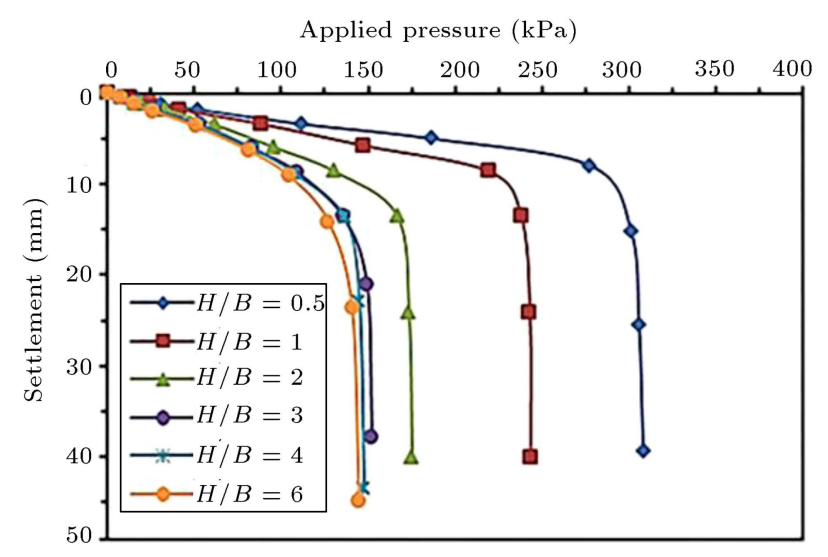

Figure 2. Pressure-settlement curves for unreinforced sand at various $H / B$. 
Table 2. Equivalent Bearing Capacity (BC) factor $N_{\gamma} S_{\gamma}$ values resulting from different approaches.

\begin{tabular}{|c|c|c|c|c|c|c|c|c|c|c|c|}
\hline \multicolumn{2}{|c|}{$\begin{array}{c}\text { Lyamin } \\
\text { et al. [ } 7] \\
\text { Lower bound }\end{array}$} & \multicolumn{2}{|c|}{$\begin{array}{c}\text { Lyamin } \\
\text { et al. [7] } \\
\text { Upper bound }\end{array}$} & \multicolumn{2}{|c|}{$\begin{array}{c}\text { Erickson } \\
\text { and Drescher } \\
\text { [5] FDM }\end{array}$} & \multicolumn{2}{|c|}{$\begin{array}{c}\text { Loukidis } \\
\text { and Salgado } \\
\text { [6] FEM }\end{array}$} & \multirow{2}{*}{$\begin{array}{l}\text { De Beer } \\
\text { [9] Test } \\
\varphi=36\end{array}$} & \multirow{2}{*}{$\begin{array}{c}\text { Bolton } \\
\text { and Lau }[8] \\
\text { method of } \\
\text { characteristics } \\
\varphi=36\end{array}$} & \multirow{3}{*}{$\begin{array}{c}\text { Present } \\
\text { study } \\
(H / B=4) \\
\varphi=36\end{array}$} & \multirow{2}{*}{$\begin{array}{c}\text { Large } \\
\text { scale } \\
\text { test }[11] \\
\varphi=36\end{array}$} \\
\hline$\varphi=35$ & $\varphi=40$ & $\varphi=35$ & $\varphi=40$ & $\varphi=35$ & $\varphi=40$ & $\varphi=35$ & $\varphi=40$ & & & & \\
\hline 37.2 & 106.6 & 52.5 & 157.2 & $33-73^{\mathrm{a}}$ & $45-130^{\mathrm{a}}$ & $42^{\mathrm{b}}$ & $122.2^{\mathrm{b}}$ & $28-57$ & 101 & & 55 \\
\hline
\end{tabular}

Mohr-Coulomb failure envelope [37]. Mohr-Coulomb failure criterion is given in a straight line at small shear stress becoming curved at high stresses. The value of curvature in dense sands at higher stress is greater than in loose sands. The friction angle of loose sand are not affected by pressure, therefore, reduction in the rate of increase of pressure with width does not occur in loose sand. The BC in sands is also affected by both peak and critical state strengths values. Strength of sand is a function of dilation which is a function of relative density and would not be uniform below a loaded footing. Thus, a complicated relation is needed to take this into account justifying for practical purposes the use of a simplified method [38].

\subsubsection{Validity of tests}

Table 2 shows $N_{\gamma} S_{\gamma}$ produced from test results using Eq. (3) for single circular footings on sand with $H / B=4$ (which is the same as infinite layer) and those reported by other investigations resulting from finite element simulation, limit analysis, method of characteristics, and experimental approaches. Good agreement can be observed with the present study. The difference between De Beer [9] results with the present and other studies can be attributed to the definition of the BC point on the pressure-settlement curve. The results given in Table 2 can be used to establish values for the $\mathrm{BC}$ and shape factors of circular footings. In traditional relations in foundation engineering, it has been assumed that the solution for a square load/foundation can be estimated by the solution for a circular footing, which is much easier to calculate because of the axial symmetry of these footings.

Figure 3 compares $N_{\gamma}^{*} S_{\gamma}^{*}$ versus $H / B$ of the present study with those from other reports and large scale models. These differences between results can change depending on relative density, footing diameter, soil properties, and the procedure adopted for $\mathrm{BC}$ determination from the pressure-settlement curves. As can be observed, decreasing $H / B$ from 6 to 0.5 results in increasing $\mathrm{BC}$ and shape factors approximately in the range of $0-225 \%$ as obtained from Eq. (3). Figure 3 also shows $N_{\gamma}^{*} S_{\gamma}^{*}$ values in the large scale model are smaller than those obtained from the small scale one, which is attributed to the failure mechanism and the scale effect problem. Scale effect is the experimental size, or scale, effect of the laboratory models on the BC.

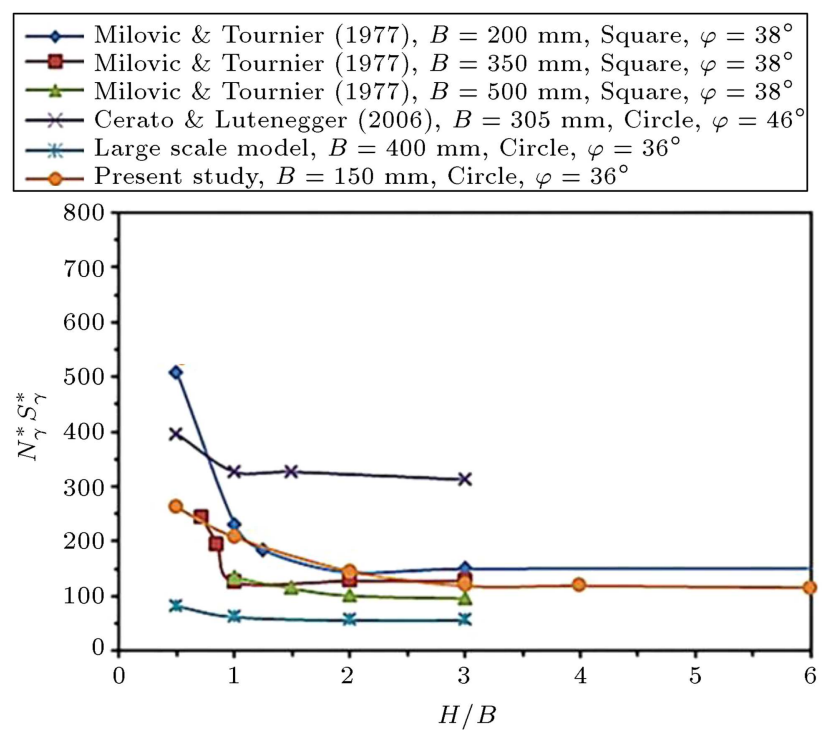

Figure 3. Comparison of measured $N_{\gamma}^{*} S_{\gamma}^{*}$ with those suggested by others.

\subsubsection{Reinforced case}

The bearing pressure settlement curves for footing on a GCR sand bed are also presented in Figure 4. As seen, the BC of GCR single circular footings is about 1.69-1.83 greater than without unreinforced cases at the same value of $H / B$. With GCR sand, no clear failure could be observed except for a slight reduction in the slope of the pressure-settlement curve due to the reinforcing effect leading to significant decrease in both the vertical stresses and settlement.

The shear and bending stiffness of the geocell

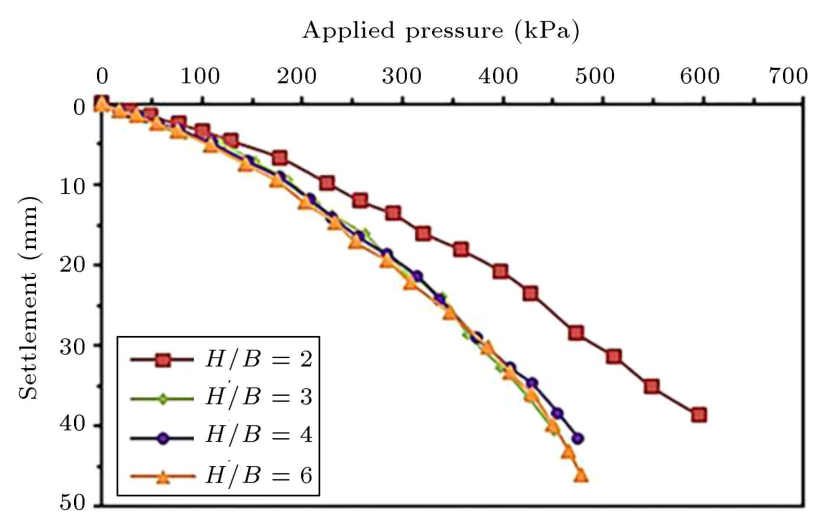

Figure 4. Pressure-settlement variation for circular footing on geocell-reinforced (GCR) sand for various $H / B$. 


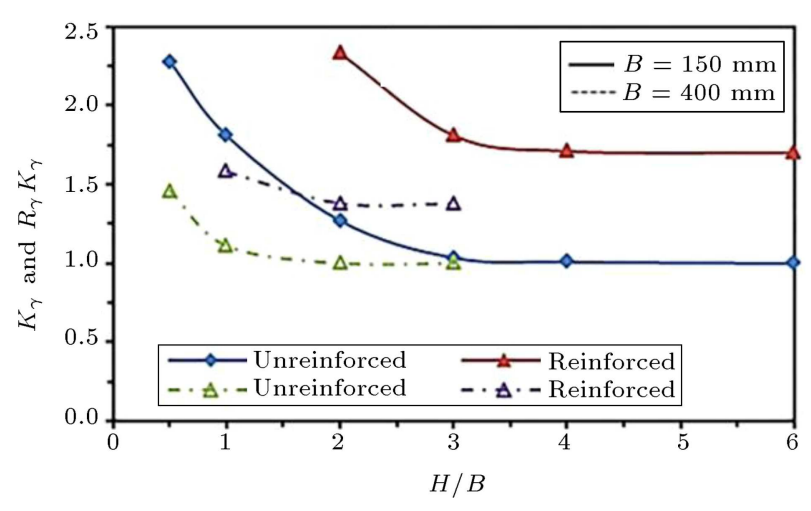

Figure 5. Variation of $K_{\gamma}$ and $R_{\gamma} K_{\gamma}$ in term of $H / B$ for a single circular footing on unreinforced and geocell-reinforced (GCR) sand.

support the sand under the load even after the failure. The geocell mattress acts as a plate, distributing pressures over a larger volume, and, in effect, increases soil stiffness [39]. It can be stated that, with the provision of geocell reinforcement and decreasing $H / B$, substantial performance improvement in the settlement and $\mathrm{BC}$ of the circular footing occurs without significant influence on the critical depth.

The variations of $K_{\gamma}$ at different $H / B$ values for a single circular footing on unreinforced sand are expressed in Figure 5. To calculate $K_{\gamma}$ in Figure 5, $H / B=4$ is considered adequate to ensure no rigid base effect below the footing, and $H / B=4$ can be assumed for footing located on an infinite layer. For comparison, the results of a large scale model performed in another study [11] are also presented in Figure 5. It can be observed that critical depth and $K_{\gamma}$ obtained from small scale tests are greater than those obtained from large model tests. On the other hand, $N_{\gamma}$ decreases with increasing footing size, due to the increasing intensity of stress beneath the footing, which resulted in a decreasing friction angle. Previous studies also state that $S_{\gamma}$ can also impress from scale effect phenomenon, especially when foundation geometry becomes more three dimensional [40].

Figure 5 also presents variation of $R_{\gamma} K_{\gamma}$ for GCR cases for different locations of the rigid base. The results show the rigid base plays a significant role in the $\mathrm{BC}$ and settlement of footing located on GCR sand. By comparing the results of the current study with large scale model tests, it is observed that the reinforcement effect on the behavior of smaller footing is more pronounced than larger footing. The diameter of larger scale footing is approximately twice the equivalent diameter of one cell pocket of the geocell reinforcement, and all the cell walls are covered completely by the footing circumference. In small scale tests, a footing diameter is smaller than the equivalent diameter of one pocket cell protecting one cell and no cell walls exist directly beneath the footing. Therefore, local effects on the results might occur by the location of the cell walls relative to the footing diameter [41].

\subsection{Twin footings on unreinforced sand}

The set of pressure-settlement plots for twin footings on unreinforced sand is seen in Figure 6 for different values of $d / B$ and $H / B$. The results show that substantial increase in the $\mathrm{BC}$ occurs for twin compared to single footing due to interference effects. With increasing $d / B$ the $\mathrm{BC}$ decreases when the rigid base depth is constant. Maximum $\mathrm{BC}$ occurs when $d / B=1$ for shallower base depth. This is mainly due to increased confinement of the sand from the extra foundation and the more roles a rigid base plays at shallow depths. In case of $d / B>3$, the behavior of each footing is approximately the same as for the single footing. The rigid base depth has also a substantial effect on the interference influence. On the other hand, decreasing the depth of the rigid base decreases remarkably the interference effect. When the rigid base is at a depth of $H / B=4$, the interference effect for various footing distances is greater compared to $H / B=0.5$. Similar observation was reported by Nainegali et al. [42] by numerical simulation for twin strip footings located on sand. By comparing the results of the $\mathrm{BC}$ for $H / B=3$ and 4 at different $d / B$ in Figure 6, it can be seen that the critical depth for two adjacent circular footings may extend beyond $3 B$ due to overlapping of failure zones. In other words, the critical depths of twin footings penetrate deeper than in single isolated footings [31]. It is worth mentioning, however, that critical depths in the larger model tests of twin footings are limited to $2 B$. This is due to a difference in failure mechanisms relative to smaller scale models. Actually, failure modes in larger scale models are general failure while in small footings tend to punching.

\subsection{The general case: Twin footings on GCR sand}

The pressure-settlement responses for the general case are shown in Figure 7 for different values of $d / B$ and $H / B$. The significant increase observed in $\mathrm{BC}$ compared to twin footings on unreinforced sand at the same $H$, resulted from extra confinement in the soil beneath the footings. In the general case, all three types of confinements (twin footing, rigid base, and GCR) remarkably increase BC and decrease the settlement of footings. With twin footings on the reinforced sand, increasing spacing $d$ reduces $B C$ and decreasing $H$ reduces the interference effect.

As in the unreinforced cases, the critical depth for twin footings on GCR sand is $H / B>3$, which is deeper than for the single footing. Also, geocell reinforcement does not seriously influence critical depth when the results are compared with unreinforced cases. 

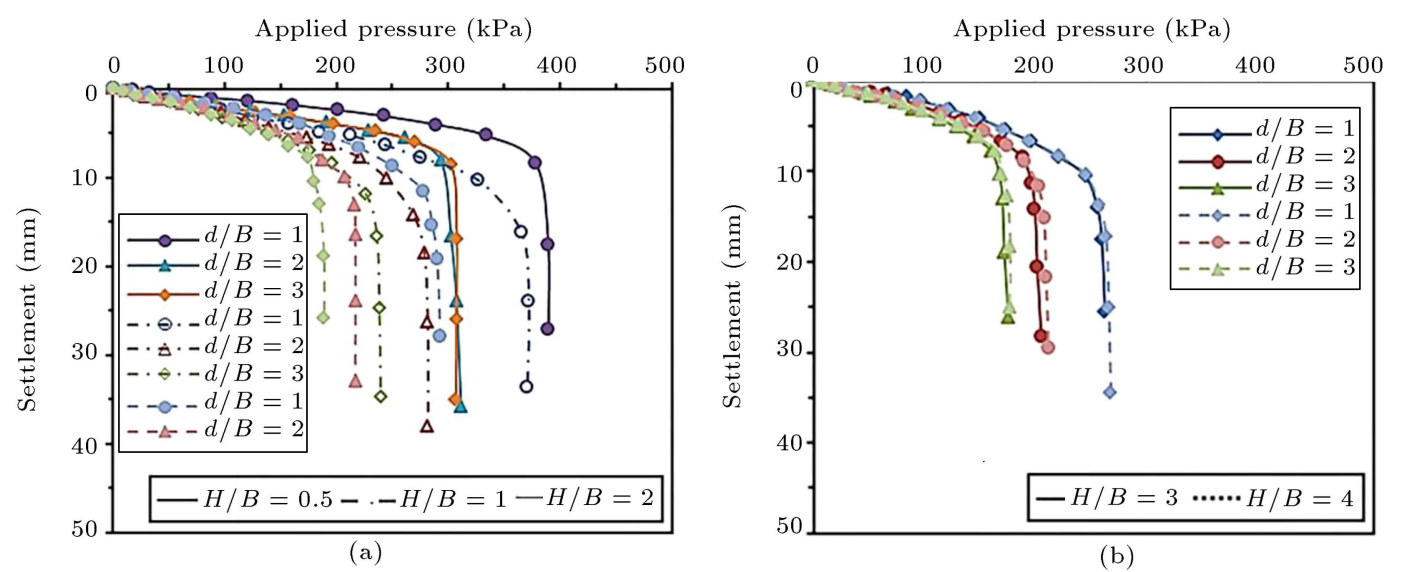

Figure 6. Pressure-settlement curves for twin footings on unreinforced sand: (a) $H / B=0.5,1$, and 2 and (b) $H / B=3$ and 4 .

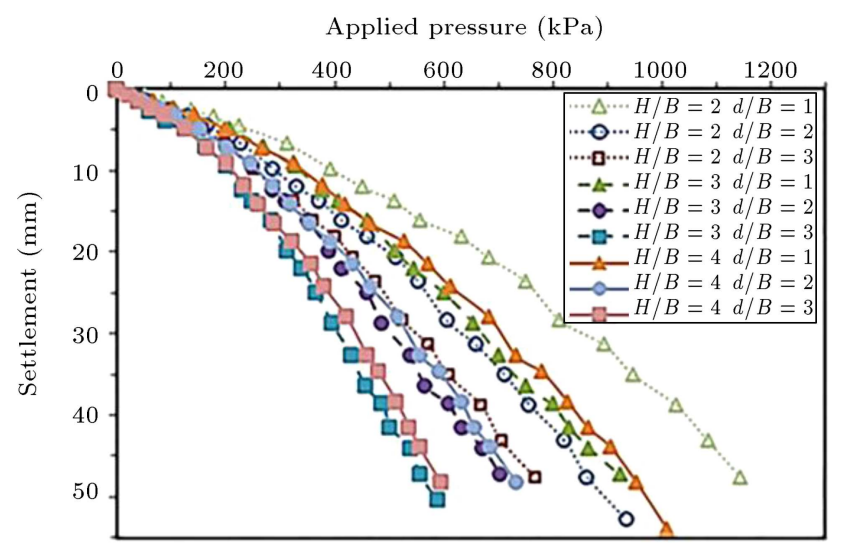

Figure 7. Pressure-settlement curves for twin footings on geocell-reinforced (GCR) sand at various $H / B$ and $d / B$.

Figure $8(\mathrm{a})$ indicates variation of $\zeta_{\gamma}^{*}$ due to interference for unreinforced cases for all $H / B$ and $d / B$ values. As observed, $\zeta_{\gamma}^{*}$ increases with $H$. Maximum $\zeta_{\gamma}^{*}$ occurs when two footings are closer and a rigid base is deeper. When a rigid base is at shallower depth and when spacing between footings is greater than $3 B, \zeta_{\gamma}^{*}$ is approximately 1 , due to a decrease in the interaction

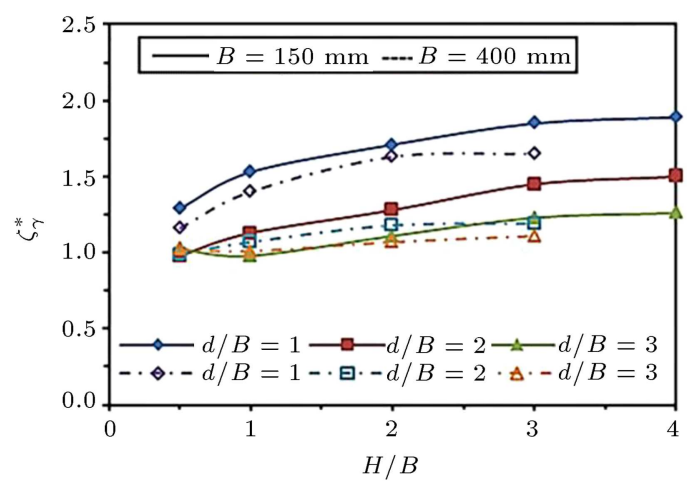

(a) effect between footings. A rigid base modifies $\zeta_{\gamma}^{*}$ and restricts interaction beneath footings. The same as for $N_{\gamma}^{*}$ and $S_{\gamma}^{*}$ factors, $\zeta_{\gamma}^{*}$ for smaller scale footings is greater than those for larger footings due to the effect of footing size.

Figure $8(\mathrm{~b})$ shows $\zeta_{\gamma}^{*}$ values for GCR sand for all cases considered. $\zeta_{\gamma}^{*}$ changes from 1.16 to 2.02 for all $H / B$ and $d / B$ values. Similar to unreinforced sand $\zeta_{\gamma}^{*}$ increases with increasing $H$. The value of $\zeta_{\gamma}^{*}$ for twin footings on reinforced sand is greater than that of unreinforced cases. Geocell reinforcement increases the interference effect and decreases settlement and deformation between footings. The values of $\zeta_{\gamma}^{*}$ for small scale models are 1.48-1.86 time greater than those obtained from the larger scale footings due to the influence of footing dimension.

\subsection{Effect of the rigid base and interference on $B C R$ and $R E F$}

Figure $9(\mathrm{a})$ shows variation of BCR in terms of $d / B$ for different values of $H / B$ according to $\mathrm{Eq}$. (8). The BCR values vary from 1.63 to 1.92 when $H / B \geq 2$ and $1 \leq d / B \leq 3$. Maximum $\mathrm{BCR}$ is when $d / B=1$

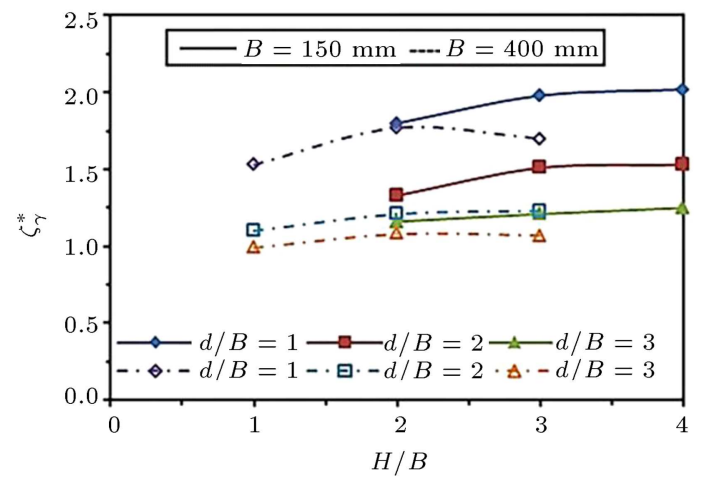

(b)

Figure 8. Variation of $\zeta_{\gamma}^{*}$ in term of $H / B$ at different values of $d / B$ for twin footings: (a) Unreinforced and (b) geocell-reinforced (GCR). 


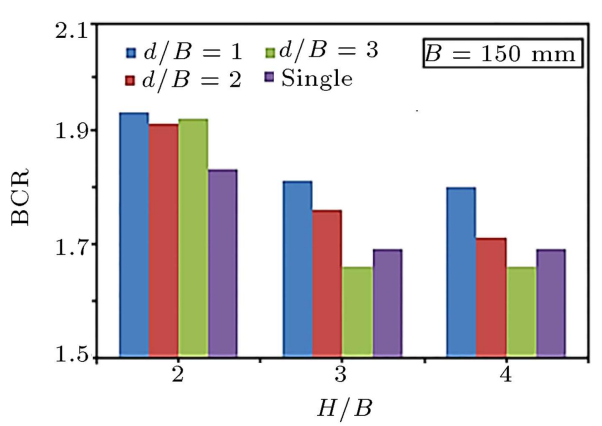

(a)

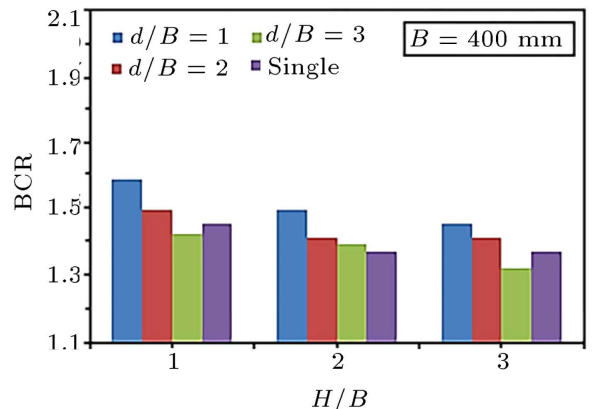

(b)

Figure 9. Variation of Bearing Capacity Ratio (BCR) versus $H / B$ at different values of $d / B$ for two adjacent footings on geocell-reinforced (GCR) sand: (a) $B=150 \mathrm{~mm}$ and (b) $B=400 \mathrm{~mm}$.

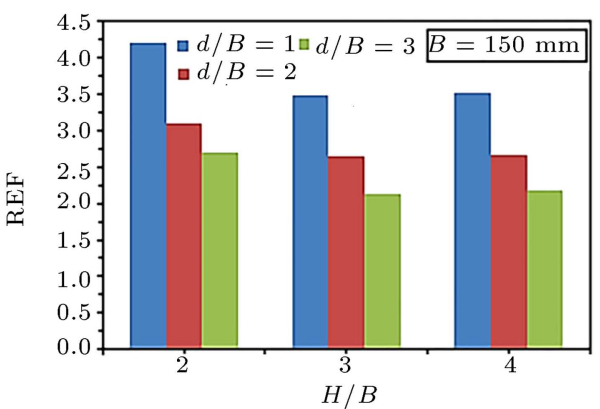

(a)

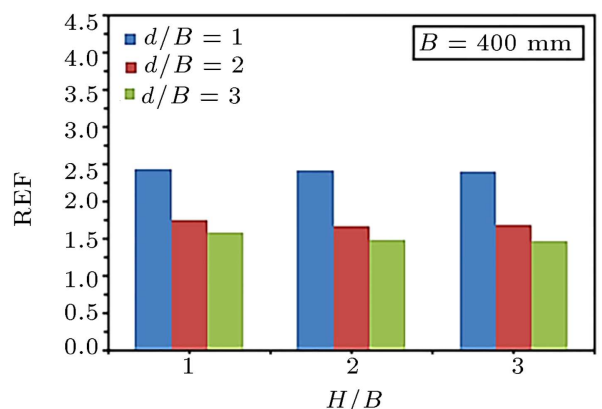

(b)

Figure 10. Variation of Ratio Efficiency Factor (REF) versus $H / B$ at different $d / B$ for two adjacent footings: (a) $B=150 \mathrm{~mm}$ and (b) $B=400 \mathrm{~mm}$.

and $H / B=2$, due to the rigid base. With increasing $H / B$, the BCR value decreases substantially. BCR results show that the presence of geocell reinforcement has significantly contributed to the increase in bearing pressure and created more confinement in the soil beneath the footings, resulting in increasing the $\mathrm{BC}$ of two nearby footings. Also, BCR is in most cases greater for twin than for single footings due to more confinement. The BCR ratio resulting from each of the twin footings is 1.07 to 0.98 times greater than those obtained from a single isolated footing of similar areas depending on the spacing between footings and location of the rigid base. By increasing $H / B$ and $d / B$, the BCR value of each of the twin footings is closer to a single similar size footing with a similar reinforcement depth and dimensions. BCR as presented in Figure 9(b) indicate lower values for the larger scale physical models.

The value of REF which shows BC increase, due to the effect of all three confinements at the same time, versus $H / B$ and $d / B$, is presented in Figure 10(a). The results show REF variation between 3.33-1.92 for $H / B \geq 2$ in the smaller models decreasing significantly with increasing $H / B$ and $d / B$. Maximum REF occurs when $d / B=1$ and $H / B=2$ for the general case. The presence of all confinement types simultaneously increased the $\mathrm{BC}$ more than 4 times. REF in the larger models, as can be seen in Figure 10(b), is smaller than that in the smaller models. The results show that in some cases REF can be more than $85 \%$ higher than in the larger scale models.

\section{Comparison of the results}

Table 3 compares $H_{c r} / B$ ratio and $K_{\gamma}$ obtained from the present study with other experimental, theoretical, and numerical data available in the literature. The differences between the present study and results from others are due to differences in footing width/diameter scale and shape, soil properties, and modeling (experimental/computational), leading to different failure mechanisms beneath the footing. All investigations show that increasing relative density and decreasing footing width results in increasing $H_{c r}$ and $K_{\gamma}$.

Table 4 presents $\zeta_{\gamma}^{*}$ and $R \zeta_{\gamma}^{*}$ resulting from this study for the unreinforced and GCR cases. Differences with values reported in the previous studies, are due to difference in $H$, footing size, shape, and relative density. All mentioned reports show that $R_{\gamma}$ is larger than 1 and the reinforcement has a significant influence on interference effect.

\section{Limitation and applicability}

The results presented in the current study provideencouragement for the application of geocell reinforcement under twin footings in the presence or absence 
Table 3. Summary of previous results performed on limited layer of sand and relation between the critical depth to footing width ratio and soil relative density.

\begin{tabular}{|c|c|c|c|c|c|c|c|}
\hline $\begin{array}{l}\text { Shape of } \\
\text { footing }\end{array}$ & Reference & $\begin{array}{c}\text { Footing } \\
\text { width/ } \\
\text { diameter } \\
(\mathrm{mm})\end{array}$ & $\begin{array}{c}H / B \\
\text { range }\end{array}$ & $\boldsymbol{H}_{c r} / \boldsymbol{B}$ & $K_{\gamma}$ & $D_{r}(\%)$ & Description \\
\hline Rectangle & Pfeifle and Das [12] & 51 & $0.4-5$ & 2.1 & $1-4.95$ & 78 & $\begin{array}{l}\text { Test, } \varphi=43^{\circ} \mathrm{a} \\
D_{50}=0.6 \mathrm{~mm}\end{array}$ \\
\hline Square & Tournier and Milović [13] & $\begin{array}{l}200,350 \\
500\end{array}$ & $0.5-6.8$ & 1.6 & $1-4.1$ & 66 & $\begin{array}{c}\text { Test, } \varphi=37^{\circ} \mathrm{a} \\
D_{50}=0.6 \mathrm{~mm}\end{array}$ \\
\hline Square & Eid et al. [14] & 120 & $0.5-6$ & $0.95-1.9$ & $1-3.1$ & $44-71$ & $\begin{array}{l}\text { Test }+ \text { Num. } \\
\varphi=37-46^{\circ} \mathrm{b} \\
D_{50}=0.21 \mathrm{~mm}\end{array}$ \\
\hline $\begin{array}{l}\text { Circle \& } \\
\text { rectangle }\end{array}$ & Siraj-Eldine and Bottero [15] & 50,56 & $0.5-3$ & 2 & - & 71 & $\begin{array}{c}\text { Test, } \varphi=35^{\circ} \mathrm{b} \\
D_{50}=0.7 \mathrm{~mm}\end{array}$ \\
\hline $\begin{array}{l}\text { Circle \& } \\
\text { square }\end{array}$ & Cerato and Lutenegger [16] & $\begin{array}{l}102,152, \\
305\end{array}$ & $0.5-4$ & 3 & - & $24-87$ & $\begin{array}{l}\text { Test, } \varphi=40.8^{\circ}-46^{\circ} \mathrm{b} \\
D_{50}=0.7 \mathrm{~mm}\end{array}$ \\
\hline \multirow[t]{2}{*}{ Circle } & Present study ${ }^{c}$ & 150 & $0.5-6$ & 3 & $1-2.28$ & 68 & $\begin{array}{l}\text { Test, } \varphi=36^{\circ}{ }^{\mathrm{a}} \\
D_{50}=0.25 \mathrm{~mm}\end{array}$ \\
\hline & Large scale model [11] & 400 & $0.5-3$ & 2 & $1-1.46$ & 68 & $\begin{array}{l}\text { Test, } \varphi=36^{\circ} \mathrm{a} \\
D_{50}=0.25 \mathrm{~mm}\end{array}$ \\
\hline
\end{tabular}

a Triaxial compressions test; ${ }^{b}$ Direct shear test; ${ }^{c}$ Single footing on unreinforced sand.

Table 4. Comparison of efficiency factors $\zeta_{\gamma}^{*}$ and $R_{\gamma} \zeta_{\gamma}^{*}$ for closely spaced footings on unreinforced and geocell-reinforced (GCR) sand.

\begin{tabular}{|c|c|c|c|c|c|c|c|c|c|}
\hline \multirow{2}{*}{$\begin{array}{c}\text { Footing } \\
\text { shape }\end{array}$} & \multirow[t]{2}{*}{ Reference } & \multirow[t]{2}{*}{$N$} & \multicolumn{6}{|c|}{$d / B$} & \multirow[t]{2}{*}{ Description } \\
\hline & & & 1 & 1.5 & 2 & 2.5 & 3 & 4 & \\
\hline \multirow[t]{4}{*}{ Square } & Kumar and Saran [17] & 0 & 1.4 & 1.9 & 1.4 & 1.2 & - & - & Test, $\varphi=37^{\circ}, D_{r}=60 \%, B=10 \mathrm{~cm}, \mathrm{SP}$, \\
\hline & & 1 & $1.1^{\mathrm{a}}$ & $1.2^{\mathrm{a}}$ & $1.1^{\mathrm{a}}$ & $1.1^{\mathrm{a}}$ & - & - & $\mathrm{EA}($ geogrid $)=20 \mathrm{kN} / \mathrm{m}$ \\
\hline & Alimardani Lavasan and Ghazavi [18] & 0 & 1.5 & 1.7 & 1.9 & 1.6 & & & Num., $\varphi=35^{\circ}$ \\
\hline & & 1 & 2.1 & 2.4 & 2.7 & 2.2 & - & - & \\
\hline \multirow[t]{12}{*}{ Circle } & Alimardani Lavasan and Ghazavi [19] & 0 & 1.3 & 1.6 & 1.2 & - & - & - & Test, $\varphi=34^{\circ}, D_{r}=40 \%, B=40 \mathrm{~cm}, \mathrm{SP}$, \\
\hline & & 1 & 1.6 & 1.8 & 1.4 & - & - & - & $\mathrm{EA}($ geogrid $)=5.5 \mathrm{kN} / \mathrm{m}$ \\
\hline & Alimardani Lavasan and Ghazavi [19] & 0 & 1.6 & 1.3 & 1.2 & 1.2 & - & - & \\
\hline & & 1 & 1.9 & - & 1.4 & - & - & - & \\
\hline & Naderi and Hataf [21] & 0 & 1.27 & - & 1.21 & - & 1.08 & 1.02 & Test + Num. $\varphi=43^{\circ}, D_{r}=50 \%, B=12 \mathrm{~cm}, \mathrm{SW}$, \\
\hline & & 1 & 2.41 & - & 2.03 & - & 1.94 & 1.84 & $\mathrm{EA}($ geogrid $)=30 \mathrm{kN} / \mathrm{m}$ \\
\hline & Alimardani Lavasan et al. [20] & 0 & 1.48 & - & 1.25 & - & 1.1 & 1.07 & Physical+Num., $\varphi=35.8$ \\
\hline & & 1 & 2 & - & 1.4 & - & 1.3 & 1.2 & \\
\hline & Present study $(H / B=4)$ & 0 & 1.89 & - & 1.50 & - & 1.26 & - & Test, $\varphi=36^{\circ}, D_{r}=68 \%, B=15 \mathrm{~cm}, \mathrm{SP}$ \\
\hline & & 1 & 3.16 & - & 2.57 & - & 2.10 & - & $\mathrm{EA}($ geocell $)=21 \mathrm{kN} / \mathrm{m}$ \\
\hline & Large scale model $(H / B=3)[11]$ & 0 & 1.65 & - & 1.19 & - & 1.11 & - & \\
\hline & & 1 & 2.37 & - & 1.68 & - & 1.47 & - & \\
\hline
\end{tabular}

${ }^{a}$ Value corresponding to $\zeta_{\gamma}$ for interfering footings on reinforced sand to $\zeta_{\gamma}$ for the same arrangement on unreinforced cases.

of a rigid base. It is worth mentioning however, that the experimental results are obtained for only one type of geocell reinforcement, one pocket size, length and height of the geocell, one type of sand and relative density. Thus, generalization of these results can only be made after considering the above mentioned limitations. Furthermore, the results herein are based on tests carried out on a circular foundation under three dimensional loading conditions. For other conditions, similar test programs have to be conducted, such as for square or strip footings, especially with a larger size. Although localized shear failure is known for narrow foundations, previous studies indicate that in granular soils reinforced by geosynthetic [43], a general shear failure mechanism occurs in both large and small scale models. Thus, the general trends obtained here are expected to be similar at full size. Therefore, future tests need to be performed with larger 
scale footings in various sizes, with different geometry, pocket size for the geocell, and relative density for sand.

\section{Scale effect}

Considering the scaling effect is necessary in order to simulate soil and reinforcement properties to obtain applicable results for practical purposes. This phenomenon prevents direct comparison of the physical model made with a full scale model. Although the results of the present study can be different to full scale footing behavior in the field, the general trend may be similar to scale the geometrical dimensions of each effective factor. Scaling factor converts design parameters from a small or large scale model into design parameters for a large prototype defining factor of $\lambda$, which indicates the diameter ratio of the prototype foundation to the diameter of the physical model footing. Also, reinforcement employed at the prototype should be $\lambda^{2}$ reinforcement used in the physical model, according to Langhaar [44] and Buckingham [45]. It is not possible using geocell reinforcement with $\lambda^{2}$ stiffer than those used here as this would be much beyond the stiffness of commercially available geocell reinforcement. The results, however, help to distinguish a general trend for scale influence, and the difference in behavior of small to large models at laboratory scale and those in full scale reinforced footing. Generally, this study provides insight into the basic mechanism that creates the bearing pressure-settlement response of the GCR sand bed combined with rigid base effects. These results would be useful in designing a laboratory to field scale tests and their simulations through numerical models.

\section{Conclusions}

A number of tests on circular twin footings supported by unreinforced and geocell-reinforced (GCR) sand overlying a rigid base are performed. A commercially available geocell made of high-density polyethylen (HDPE) is employed in the tests. The effects of a rigid base situation, footing interference and geocell reinforcement, as three different confinements, on the footing Bearing Capacity (BC) are investigated. Fixing geocell geometry and location under optimum conditions, the bounded sand layer thickness varied $0.5 B$ to $6 B$ and twin footings at spaces varying from $1 B$ to $3 B$. In the present study, for the adopted testing procedure and materials used, the following conclusions may be cited from the results:

- BC, BC factors, and settlements of twin footings are functions of the material properties and relative dimensions of geocell reinforcement, sand layer and foundations; interference from boundary confinements and interaction between base, geocell reinforcement and the foundations; model scale in relation to the other problem dimensions;

- Foundation model size effect is significant. Classical $\mathrm{BC}$ equations can be modified for special and combined cases such as reinforced soil, twin footings and bounded soil. As shown here, modified BC factors can be back calculated for the combined parameters lumped in non-dimensional plots of the $\mathrm{BC}$ using a reference case with an available design solution. Using more than one foundation model dimension provides corrections that include the influence of the footing scale;

- Critical depths of circular twin footings on GCR sand and rigid base can increase to a ratio $H / B$ in excess of more than 3 , which is much deeper than that of single unreinforced, unbounded footings of similar dimensions;

- Smaller footings on unreinforced and GCR sand result in greater critical depths than those resulting from larger footings due to scale effect;

- The maximum $\mathrm{BC}$ of twin footings on unreinforced and GCR sand is reached when $d / B=1$, with the rigid base located at a shallower depth;

- Interference effects in twin circular footings decrease remarkably with decreasing rigid base depth. Increasing the depth of the rigid base increases the efficiency factors of BC $\left(\zeta_{\gamma}^{*}\right)$;

- More tests are recommended to address some limitations in the current study. It is recommended to employ other sand relative densities, geocell reinforcement dimensions and depths. Scale effect can best be investigated in combination with a numerically calibrated simulation of the current results to extend the problem parameters and model scales.

\section{Nomenclature}

$b \quad$ Width of the geocell layer

$B \quad$ Footing width $(\mathrm{mm})$

$C_{c} \quad$ Coefficient of curvature (dimensionless)

$C_{u} \quad$ Coefficient of uniformity (dimensionless)

$d \quad$ Center to center distance between two footings

$D \quad$ Geocell pocket size (mm)

$D_{50} \quad$ Medium grain size $(\mathrm{mm})$

$D_{r} \quad$ Relative density (dimensionless)

$G_{s} \quad$ Specific gravity of soil (dimensionless) 
$h \quad$ Height of geocell layers $(\mathrm{mm})$

$H \quad$ Thickness of soil layer $(\mathrm{mm})$

$H_{c r} \quad$ Critical thickness of soil layer $(\mathrm{mm})$

$K_{\gamma} \quad$ Correction bearing capacity factor (dimensionless)

$L \quad$ Footing length $(\mathrm{mm})$

$N \quad$ Number of geocell reinforcement layers (dimensionless)

$q_{u} \quad$ Applied pressure on the footing surface $(\mathrm{kPa})$

$R_{\gamma} \quad$ Reinforcement factor (dimensionless)

$S \quad$ Footing settlement $(\mathrm{mm})$

$u \quad$ Embedded depth of the geocell (mm)

$\varphi \quad$ Angle of frictional resistance of soil (degree)

$N_{\gamma} \quad$ Bearing capacity factor (dimensionless)

$S_{\gamma} \quad$ Shape factor (dimensionless)

$N_{\gamma}^{*} \quad$ Modified bearing capacity factor (dimensionless)

$S_{\gamma}^{*} \quad$ Modified shape factor (dimensionless)

$\zeta_{\gamma} \quad$ Efficiency factor related to the bearing capacity (dimensionless)

$\zeta_{\delta} \quad$ Efficiency factor related to the settlement (dimensionless)

$\zeta_{\gamma}^{*} \quad$ Modified efficiency factor (dimensionless) Unit weight $\left(\mathrm{kN} / \mathrm{m}^{3}\right)$

Dry unit weight $\left(\mathrm{kN} / \mathrm{m}^{3}\right)$

The diameter ratio of prototype footing to diameter of model footing (dimensionless)

\section{References}

1. Mandel, J. and Salençon, J. "Force portante d'un sol sur une assise rigide (étude théorique)", Géotechnique, 22(1), pp. 79-93 (1972).

2. Stuart, J.G. "Interference between foundations, with special reference to surface footings in sand", Géotechnique, 12(1), pp. 15-22 (1962).

3. Meyerhof, G.G. "Ultimate bearing capacity of footings on sand layer overlying clay", Canadian Geotechnical Journal, 11(2), pp. 223-229 (1974).

4. De Beer, E.E. "The scale effect on the phenomenon of progressive rupture in cohesionless soils", Int. Conf. In Soil Mech. and Found. Engrg., 2, Canada, pp. 13-17 (1965).

5. Erickson, H.L. and Drescher, A. "Bearing capacity of circular footings", Journal of Geotechnical and Geoenvironmental Engineering, ASCE, 128(1), pp. 38-43 (2002).
6. Loukidis, D. and Salgado, R. "Bearing capacity of strip and circular footings in sand using finite elements", Computers and Geotechnics, 36(5), pp. 871879 (2009).

7. Lyamin, A.V., Salgado, R., Sloan, S.W., and Prezzi, M. "Two- and three-dimensional bearing capacity of footings in sand", Géotechnique, 57(8), pp. 647-662 (2007).

8. Bolton, M.D. and Lau, C.K. "Vertical bearing capacity factors for circular and strip footings on MohrCoulomb soil", Canadian Geotechnical Journal, 30(6), pp. 1024-1033 (1993).

9. De Beer, E.E. "Experimental determination of the shape factors and the bearing capacity factors of sand", Géotechnique, 20(4), pp. 387-411 (1970).

10. Al-Ashou, M., Sulaiman, R., and Mandal, J. "Effect of number of reinforcing layers on the interference between footings on reinforced sand", Indian Geotechnical Journal, 24(3), pp. 285-301 (1994).

11. Fazeli Dehkordi, P., Ghazavi, M., Ganjian, N., and Karim, U.F.A. "Effect of geocell-reinforced sand base on bearing capacity of twin circular footings", Geosynthetics International, 26(3), pp. 224-236 (2019).

12. Pfeifle, T.W. and Das, B.M. "Bearing capacity of surface footings on sand layer resting on a rigid rough base", Soils and Foundations, 19(1), pp. 1-11 (1979).

13. Tournier, J.P. and Milović, D.M. "Étude expérimentale de la capacité portante d'une couche compressible d'épaisseur limitée", Géotechnique, 27(2), pp. 111-123 (1977).

14. Eid, H.T., Alansari, O.A., Odeh, A.M., Nasr, M.N., and Sadek, H.A. "Comparative study on the behavior of square foundations resting on confined sand", Canadian Geotechnical Journal, 46(4), pp. 438-453 (2009).

15. Siraj-Eldine, K. and Bottero, A. "Étude expérimentale de la capacité portante d'une couche de sol pulverulent d'épaisseur limitée", Canadian Geotechnical Journal, 24(2), pp. 242-251 (1987).

16. Cerato, A.B. and Lutenegger, A.J. "Bearing capacity of square and circular footings on a finite layer of granular soil underlain by a rigid base", Journal of Geotechnical and Geoenvironmental Engineering, ASCE, 132(11), pp. 1496-1501 (2006).

17. Kumar, A. and Saran, S. "Closely spaced footings on geogrid-reinforced sand", Journal of Geotechnical and Geoenvironmental Engineering, ASCE, 129(7), pp. 660-664 (2003).

18. Ghazavi, M. and Alimardani Lavasan, A. "Interference effect of shallow foundations constructed on sand reinforced with geosynthetics", Geotextiles and Geomembranes, 26(5), pp. 404-415 (2008).

19. Alimardani Lavasan, A. and Ghazavi, M. "Behavior of closely spaced square and circular footings on reinforced sand", Soils and Foundations, 52(1), pp. 160-167 (2012). 
20. Alimardani Lavasan, A., Ghazavi, M., and Schanz, T. "Analysis of interfering circular footings on reinforced soil by physical and numerical approaches considering strain-dependent stiffness", International Journal of Geomechanics, ASCE, 17(11), 04017096 (2017).

21. Naderi, E. and Hataf, N. "Model testing and numerical investigation of interference effect of closely spaced ring and circular footings on reinforced sand", Geotextiles and Geomembranes, 42(3), pp. 191-200 (2014).

22. Roy, S.S. and Deb, K. "Closely spaced rectangular footings on sand underlain by soft clay with geogrid at the interface", Geosynthetics International, 25(4), pp. 412-426 (2018).

23. Terzaghi, K., Theoretical Soil Mechanics, John Wiley, NY (1943).

24. Brown, R., Valsangkar, A.J., and Schriver, A.B. "Centrifuge modeling of surface footings on a sand layer underlain by a rigid base", Geotechnical and Geological Engineering, 22(2), pp. 187-198 (2004).

25. Alimardani Lavasan, A., Ghazavi, M., Blumenthal, A. Von. and Schanz, T. "Bearing capacity of interfering strip footings", Journal of Geotechnical and Geoenvironmental Engineering, ASCE, 144(3), 04018003 (2018).

26. Salamatpoor, S., Jafarian, Y., and Hajiannia, A. "Bearing capacity and uneven settlement of consecutively constructed adjacent footings rested on saturated sand using model tests", International Journal of Civil Engineering, 17, pp. 737-749 (2019).

27. Salamatpoor, S., Jafarian, Y., and Hajiannia, A. "Mitigating the uneven settlement of nearby strip footings on loose saturated sand using concrete pedestals: a model test study", Scientia Iranica, 25(4), pp. 20632076 (2018).

28. Nainegali, L., Basudhar, P.K., and Ghosh, P. "Interference of strip footings resting on nonlinearly elastic foundation bed: a finite element analysis", Iranian Journal of Science and Technology, Transactions of Civil Engineering, 42(2), pp. 199-206 (2018).

29. Alimardani Lavasan, A. and Ghazavi, M. "Failure mechanism and soil deformation pattern of soil beneath interfering square footings", Journal of Numerical Methods in Civil Engineering, 2(1), pp. 48-56 (2014).

30. Gupta, A. and Sitharam, T.G. "Experimental and numerical investigations on interference of closely spaced square footings on sand", International Journal of Geotechnical Engineering, 14(2), pp. 142-150 (2020).

31. Ghosh, P., Basudhar, P.K., Srinivasan, V., and Kunal, K. "Experimental studies on interference of two angular footings resting on surface of two-layer cohesionless soil deposit", International Journal of Geotechnical Engineering, 9(4), pp. 422-433 (2015).

32. Lee, J. and Eun J. "Estimation of bearing capacity for multiple footings in sand", Computers and Geotechnics, 36(6), pp. 1000-1008 (2009).
33. Srinivasan, V. and Ghosh, P. "Experimental investigation on interaction problem of two nearby circular footings on layered cohesionless soil", Geomechanics and Geoengineering, 8(2), pp. 97-106 (2013).

34. Dash, S.K., Krishnaswamy, N.R., and Rajagopal, K. "Bearing capacity of strip footings supported on geocell-reinforced sand", Geotextiles and Geomembranes, 19(4), pp. 235-256 (2001).

35. ITASCA, Flac, Fast Lagrangian Analysis of Continua, Version 5.0, Itasca Consulting Group, Inc. Minneapolis, MN, USA (2015).

36. Amar, S., Baguelin, F., Canepa, Y., and Frank, R. "Experimental study of the settlement of shallow foundations", Vertical and Horizontal Deformations of Foundations and Embankments, ASCE, 40(2), pp. 1602-1610 (1994).

37. Golder, H.Q., Fellenius, W., Kogler, F., Meischeider, H., Krey, H., and Prandtl, L. "The ultimate bearing pressure of rectangular footings", Journal of the Institution of Civil Engineers, 17(2), pp. 161-174 (1941).

38. De Beer, E.E. "The scale effect in the transposition of the results of deep-sounding tests on the ultimate bearing capacity of piles and caisson foundations", Géotechnique, 13(1), pp. 39-75 (1963).

39. Han, J., Yang, X., Leshchinsky, D., and Parsons, R.L. "Behavior of geocell-reinforced sand under a vertical load", Transportation Research Record: Journal of the Transportation Research Board, 2045, pp. 95-101 (2008).

40. Kusakabe, O. "Experiment and analysis on the scale effect of $N_{\gamma}$ for circular and rectangular footings", Proc. Int. Conf. Centrifuge '91, Boulder, Colorado, pp. 179-186 (1991).

41. Rajagopal, K., Krishnaswamy, N.R., and Madhavi Latha, G. "Behaviour of sand confined with single and multiple geocells", Geotextiles and Geomembranes, 17(3), pp. 171-184 (1999).

42. Nainegali, L.S., Basudhar, P.K., and Ghosh, P. "Interference of two asymmetric closely spaced strip footings resting on nonhomogeneous and linearly elastic soil bed", International Journal of Geomechanics, ASCE, 13(6), pp. 840-851 (2013).

43. Adams, M.T. and Collin, J.G. "Large model spread footing load tests on geosynthetic reinforced soil foundations", Journal of Geotechnical and Geoenvironmental Engineering, ASCE, 123(1), pp. 66-72 (1997).

44. Langhaar, J.L., Dimensional Analysis and Theory of Models, John Wiley \& Sons, New York, NY (1951).

45. Buckingham, E. "On physically similar systems; illustrations of the use of dimensional equations", Physical review, 4(4), pp. 345-376 (1914).

\section{Biographies}

Pezhman Fazeli Dehkordi is a PhD student of Geotechnical Engineering at the Islamic Azad University, Science and Research Branch, Tehran, Iran. 
He undertook part of his $\mathrm{PhD}$ requirements at the University of Twente, Netherlands. He is also an academic member of the Faculty of Civil En gineering at the Islamic Azad University, Shahrekord Branch, Iran. His main research interests are foundation engineering; ground improvement with focus on laboratory works and numerical simulations.

Mahmoud Ghazavi is Professor of Geotechnical Engineering in the Faculty of Civil Engineering at Khaje Nasir Toosi University of Technology (K.N.T.U), Tehran, Iran. His research interests include soil improvement, optimization, energy piles, shallow and deep foundation engineering using physical, numerical and analytical methods.
Navid Ganjian is Assistant Professor of Geotechnical Engineering in the Faculty of Civil Engineering at the Islamic Azad University, Science and Research Branch, Tehran, Iran. His research interests are soil improvement, shallow foundations and analytical method in geotechnical engineering.

Usama Farhan Abdul Karim is Professor in the Faculty of Civil Engineering at the University of Twente, Netherlands. His experience in research include soils, materials and testing technologies, computational geomechanics, geotechnical design software in foundations, excavations, geo-risk, geotextiles, international codes of practice for geotechnical and materials testing of soils (ASTM, EURO code, BS, NEN). 